\title{
MIRON ŁAKOMY
}

Katowice

\section{Misje pokojowe Unii Europejskiej w stosunkach francusko-amerykańskich na przełomie XX i XXI wieku}

Rozwój Wspólnej Polityki Zagranicznej i Bezpieczeństwa Unii Europejskiej, stanowił w okresie pozimnowojennym jedno $\mathrm{z}$ kluczowych zagadnień $\mathrm{w}$ stosunkach francusko-amerykańskich. W kontekście reformy Sojuszu Północnoatlantyckiego i dostosowania go do wyzwań XXI wieku, szczególne znaczenie zyskał wymiar wojskowy integracji europejskiej. Po 1989 roku jednym z głównych celów Francji oraz wspierających ją Niemiec, stało się bowiem uzyskanie przez Unię Zachodnioeuropejską a potem UE zdolności do autonomicznej projekcji sił zbrojnych w ramach misji zarządzania kryzysowego. Głównym problemem przez wiele lat były niewystarczające środki tak wojskowe, jak i finansowe. M.in. z tego powodu, w latach 90-tych Pałac Elizejski poszukiwał alternatywnych sposobów rozwoju „Europy obrony”, czego przejawem było tzw. rapprochement z Sojuszem Północnoatlantyckim. Również z tego powodu, Paryż przez lata zabiegał o możliwość wykorzystania zasobów NATO. Zostało to w pełni potwierdzone przez NATO dopiero w 2003 roku w ramach porozumień „Berlin plus”, gdyż wcześniejsze ustalenia z lat 1994 i 1996 okazały się martwą literą ${ }^{1}$. Starania V Republiki o budowę autonomicznych zdolności obronnych Europy, przez wiele lat budziły kontrowersje po drugiej stronie Atlantyku. W Stanach Zjednoczonych aspiracje Paryża odczytywano w kontekście francusko-amerykańskiej rywalizacji o wpływy na świecie. Dlatego też, Amerykanie w latach 90-tych podejmowali działania zmierzające do spowolnienia procesu rozwoju „Europy obrony”. Za przełom należy z pewnością uznać porozumienie z St. Malo w 1998 roku oraz wojnę w Kosowie, które sprawiły, iż na początku wieku XXI Unia Europejska uzyskała długo oczekiwaną zdolność do podejmowania autonomicznych wobec Sojuszu operacji wojskowych. Warto więc podjąć próbę odpowiedzi na pytanie, w jaki sposób aktywizacja działań militarnych Unii Europejskiej na arenie międzynarodowej wpłynęła na francusko-amerykański dialog na temat euroatlantyckiego systemu bezpieczeństwa w XXI wieku.

Pierwsze operacje wojskowe Unia Zachodnioeuropejska podejmowała już od końca lat 80-tych. Do najważniejszych z nich, należałoby zaliczyć: operację UZE w Zatoce Perskiej, operację Sharp Guard na Adriatyku, misję dunajską, w Mostarze oraz w Albanii. Pierwsza z nich, prowadzona pod kryptonimem Cleansweep, rozpoczęła się już w 1987 roku. Jej głównym celem było rozminowanie cieśniny Ormuz z pozostałości po wojnie iracko-irańskiej. Uczestniczyły w niej okręty Wielkiej Brytanii, Holandii, Włoch i Francji. Po zakończeniu działań wojennych w Iraku, jednostki czterech państw

1 The NATO-EU Strategic Partnership, http://www.nato.int/docu/comm/2004/06-istanbul/ press-kit/006.pdf, dostęp: 14.09.2008. 
UZE dostarczały pomoc humanitarną do tego kraju i kontynuowały akcję rozminowywania Zatoki Perskiej. Druga operacja - na Adriatyku - rozpoczęła się w lipcu 1992 roku, przy współpracy z siłami NATO. Głównym celem misji Sharp Guard było kontrolowanie przestrzegania embarga na sprzedaż broni do Jugosławii. Została ona podjęta na wniosek Organizacji Narodów Zjednoczonych i była prowadzona głównie przez siły morskie i powietrzne Francji oraz Włoch. Zakończono ją 23 listopada 1995 roku. Celem operacji dunajskiej rozpoczętej w czerwcu 1993 roku było nadzorowanie embarga na sprzedaż broni oraz sankcji ekonomicznych wobec Belgradu. Uczestniczyło w niej 250 celników i policjantów operujących na terytorium Bułgarii, Węgier i Rumunii. Przerwano ją po trzech latach w czerwcu 1996 roku. W czerwcu 1994 roku, UZE rozpoczęła natomiast misję policyjną w Mostarze w Bośni i Hercegowinie, gdzie 180 policjantów z Austrii, Szwecji i Finlandii miało za zadanie utrzymać porządek w mieście oraz odbudować zaufanie pomiędzy Chorwatami a muzułmanami. Została ona podjęta na prośbę Rady UE. Zakończono ją w październiku 1997 roku. Ostatnią większą operację w latach 90-tych Unia Zachodnioeuropejska podjęła na początku 1997 roku w Albanii, przy współpracy z Organizacją Narodów Zjednoczonych, OBWE i Unią Europejską. Głównym jej celem była stabilizacja wewnętrzna ogarniętego rozruchami państwa. UZE zdecydowała się wówczas wysłać do Albanii Wielonarodową Doradczą Jednostkę Policyjną, która miała wspierać wielonarodowe Siły Ochronne oraz pomagać miejscowym władzom przywrócić porządek. Na początku jednostka liczyła 20 osób, w kolejnych latach została rozszerzona do 100 policjantów. Misja została zakończona w 2001 roku $^{2}$.

Nie trudno zauważyć, że misje prowadzone przez Unię Zachodnioeuropejską w latach 90-tych były operacjami na niewielką skalę. Dwie poważne operacje wojskowe, na Adriatyku i w Zatoce Perskiej były realizowane przy współpracy z sojusznikiem amerykańskim, natomiast $\mathrm{w}$ działaniach policyjnych uczestniczyło $\mathrm{z}$ reguły od kilkudziesięciu do kilkuset osób, co nie wymagało od UZE/UE ani większych środków finansowych, ani struktur organizacyjnych. Zważywszy na francuskie i niemieckie ambicje budowy autonomicznych, europejskich zdolności obronnych, postulat rozwoju tożsamości UE na arenie międzynarodowej oraz ówczesny potencjał wojskowy Sojuszu Północnoatlantyckiego, misje stabilizacyjne podejmowane przez UZE/UE nie miały w zasadzie większego znaczenia w relacjach francusko-amerykańskich. Stany Zjednoczone obawiając się potencjalnego zagrożenia dla swej pozycji w przyszłości, słusznie uznały, że struktury europejskie nie miały w latach 90-tych wystarczającego potencjału dla zagrożenia pozycji NATO.

Również Pałac Elizejski w latach 90-tych zdawał sobie sprawę z faktu, że Europa Zachodnia nie jest w stanie szybko osiagnąć zdolności wojskowych porównywalnych do Stanów Zjednoczonych. Z tego przekonania wynikały próby uzyskania zgody na wykorzystanie natowskich środków wojskowych. Mimo uzgodnień z lat 1994 i 1996, w rzeczywistości dostęp państw Unii Zachodnioeuropejskiej do zasobów NATO pozostał przez lata fikcją. Jak zauważono wcześniej, bezpośrednim impulsem do szybszych

2 R. Zięba, Instytucjonalizacja bezpieczeństwa europejskiego, Warszawa 1999, s. 204-206; NATO/WEU Operation ,,Sharp Guard”, http://www.nato.int/IFOR/general/shrp-grd.htm, dostęp: 15.09.2008; R. Zięba, Europejska Tożsamość Bezpieczeństwa i Obrony, Warszawa 2000, s. 150-158. 
prac nad „Europą obrony” stała się wojna w Kosowie. W rezultacie, na szczycie w Helsinkach w 1999 roku podjęto decyzję o budowie Europejskich Sił Szybkiego Reagowania, które miały wypełniać zadania ustalone w 1992 roku w Petersbergu ${ }^{3}$.

Szybkie prace nad budową ESDP na przełomie wieków, jak również porozumienia „Berlin plus” z Sojuszem Północnoatlantyckim z 2003 roku, pozwoliły na zdecydowanie większe zaangażowanie Europy w misje zarządzania kryzysowego. Operacje te, podejmowane na początku XXI wieku miały charakter cywilny lub wojskowy. Wśród najważniejszych misji cywilnych podejmowanych przez Unię Europejską w tym okresie należy wymienić: Misję Obserwacyjną Unii Europejskiej w byłej Jugosławii (EUMM), misję Zespołu Planistycznego w Kosowie (EUPT/ZPMMC/SPUE), EUJUST-Themis w Gruzji, Misję Graniczną UE dla Ukrainy i Mołdowy (EUBAM) oraz akcje policyjne w Bośni i Hercegowinie oraz Macedonii (EUPM/EUPOL Proxima). Działaniami na mniejszą skalę, o których również należy wspomnieć, są operacje UE na Bliskim Wschodzie: EU BAM Rafah, EUPOL COPPS i EUJUST LEX ${ }^{4}$. Warto przy tym zauważyć, że operacje cywilne podejmowane przez Unię Europejską na początku XXI wieku, ze względu na swój charakter, nie wzbudzały w zasadzie żadnych kontrowersji francusko-amerykańskich.

Obok operacji o charakterze cywilnym, Unia Europejska od 2000 roku podjęła również szereg misji wojskowych, które zyskały spore znaczenie w relacjach francusko-amerykańskich. Wśród nich należy wymienić przede wszystkim: misję Concordia w Macedonii, operację Althea w Bośni i Hercegowinie, operację Artemis oraz EUFOR Congo w Demokratycznej Republice Konga, a także misję EUFOR Tchad/RCA w Czadzie.

Operacja Concordia w Macedonii była pierwszą misją wojskową UE od szczytu z Helsinek z końca lat 90-tych. Miała ona zastapić siły NATO operujące w tym państwie w ramach Task Force Fox. W dużej mierze stała się ona przykładem tego, co udało się dotychczas osiagnąć i w jaką stronę ewoluuje Europejska Polityka Bezpieczeństwa i Obrony. Concordia rozpoczęła się w kwietniu 2003 roku. Do jej głównych zadań należało: zapobieżenie wybuchowi walk pomiędzy Albańczykami a Macedończykami, utrzymanie integralności terytorialnej Macedonii, stabilizacja sytuacji wewnętrznej oraz wsparcie dla reform w tym kraju. W skład kontyngentu wysłanego przez Unię weszło tylko 400 żołnierzy z 13 państw członkowskich. W misji uczestniczyli również żołnierze z 14 państw spoza Unii Europejskiej. Cała operacja była nad wyraz krótka, gdyż już 15 grudnia 2003 roku jej zadania zostały przejęte przez siły policyjne UE w ramach operacji ,Proxima”. . Jej skala była więc niewielka, warto jednak zwrócić uwage na jej wpływ na stosunki UE-NATO. Przede wszystkim, misja ta miała rozpocząć się nieco wcześniej, co jednak nie udało się ze względu na brak porozumienia o wykorzystaniu środków sojuszniczych Paktu Północnoatlantyckiego. Dopiero jego

3 Helsinki European Council 10 and 11 December 1999. Presidency Conclusions, European Parliament, 10-11.12.1999.

4 Szerzej na temat zaangażowania Francji w te operacje w: A. Dulphy, C. Manigand, La France au risque de l'Europe, Paris 2006, s. 230.

5 Y. Boyer, Les operations militaires et de police de l'Union européenne, w: Annuaire Stratégique et Militaire 2004; C. Piana, Vers une Europe de la défense?, w: L'Union Européenne, acteur international, dir. D. Helly, F. Petiteville, Paris 2005, s. 95. 
podpisanie w połowie grudnia 2002 roku pozwoliło Unii Europejskiej podjąc działania zmierzające do rozmieszczenia wojsk na terytorium Macedonii ${ }^{6}$. Opóźnienie spowodowane niedostępnością środków NATO (i wyraźnym opóźnianiem ich przekazania przez Amerykanów) udowodniło, że zdolności Unii Europejskiej nadal są niewielkie, gdyż nie była ona w stanie, bez pomocy Sojuszu rozmieścić przy swoich granicach mniej niż 400 żołnierzy. Co więcej, z tego kontyngentu, ponad 1/4 żołnierzy dostarczyła Francja ${ }^{7}$. Bez względu na wymienione wyżej trudności, kryzys w Macedonii stał się modelowym przykładem współpracy politycznej pomiędzy Unią Europejską a NATO oraz USA i Francją ${ }^{8}$. Z inicjatywy francuskiej, Unia Europejska ustanowiła w Skopje już w 2001 roku swojego stałego przedstawiciela, którym został Francois Leotard. Świadczyło to o dużej wadze jaką Paryż przykładał do wydarzeń w tamtym regionie. W rozwiązanie kryzysu w Macedonii zaangażował się również Colin Powell oraz amerykańscy dyplomaci przy OBWE. Obie strony, unijna, wspierana przez Francję, oraz amerykańska blisko ze sobą współpracowały przy próbach zapobieżenia konfliktu. Zaowocowało to zgodą rządu w Skopje na ograniczone reformy państwa oraz podpisaniem porozumienia o rozbrojeniu Albańczyków w Macedonii 19 sierpnia 2001 roku. Umowa ta została zawarta pod patronatem Unii Europejskiej, Sojuszu Północnoatlantyckiego oraz Stanów Zjednoczonych ${ }^{9}$. Co prawda, porozumienia te okazały się nietrwałe, jednak udowodniły, że Unia Europejska, NATO i USA mogą skutecznie ze sobą współpracować przy rozwiązywaniu kryzysów. Opinię tę podzieliła Giovanna Bono, zdaniem której, Concordia pokazała, jak współpraca partnerów po obu stronach Atlantyku (szczególnie w warunkach kryzysu irackiego) powinna wygląać ${ }^{10}$.

Drugą operacją wojskową podjętą przez Unię Europejską na początku XXI wieku stała się misja Althea w Bośni i Hercegowinie. Miała ona zastapić misję natowską SFOR (Stabilisation Force), która kończyła się w 2004 roku. Co za tym idzie, konieczna okazała się kooperacja pomiędzy strukturami natowskimi a unijnymi. Jednak również i w tym wypadku okazało się, że strona amerykańska prowadzi działania opóźniające rozpoczęcie tej misji. W czerwcu 2003 roku na spotkaniu Rady Północnoatlantyckiej w Madrycie, Stany Zjednoczone stwierdziły, że planowany termin rozpoczęcia unijnej operacji w lecie 2004 r. jest nierealny. Przedstawiciel Białego Domu

${ }^{6}$ Y. Boyer, La sécurité et la défense: le temps des militaires, „Questions Internationales”, $\mathrm{nr} 7$, Fondation pour la Recherche Stratégique, s. 6; M. Musioł, Bezpośrednie zaangażowanie UE w utrzymanie pokoju w Europie, Portal Spraw Zagranicznych, 20.06.2007, s. 7, www.psz.pl; R. Zięba, Unia Europejska jako aktor stosunków międzynarodowych, Warszawa 2003, s. 121; C. Piana, op. cit., s. 95; G. Rouby, L'OTAN et l'UE. Partenariat ou concurrence?, „Annuaire Francais de Relations Internationales" 2006, vol. VII, Bruxelles 2006.

7 A. Dulphy, C. Manigand, op. cit., s. 230.

8 W tym kontekście minister spraw zagranicznych Wielkiej Brytanii Jack Straw stwierdził nawet, iż Concordia stała się początkiem „nowego strategicznego partnerstwa pomiędzy Unią Europejską a NATO. Zob. European Security and Defence Policy: operation Concordia launched, Foreign and Commonwealth Office Press Releases, 31.03.2003.

9 J. Tercinet, L'impossible monopole européen, w: La sécurité de l'Europe et les relations transatlantiques au seuil du XXI siécle, dir. Y. Jeanclos, Bruxelles 2003, s. 280-281.

${ }_{10}$ G. Bono, Operation Concordia: The first step towards a new strategic EU-NATO relationship?, www.weltpolitik.net, dostęp: 5.02.2009. 
wskazał, iż NATO nie będzie wtedy gotowe do przekazania odpowiedzialności za stabilność tego państwa Unii Europejskiej ${ }^{11}$. Wywołało to zrozumiałą irytację Paryża i innych państw UE, które chciały operację rozpocząc jak najszybciej. Althea została w końcu podjęta na początku grudnia 2004 roku. Jej celem było zapewnienie stabilizacji i sprawnego funkcjonowania struktur państwowych Bośni i Hercegowiny. Zadanie to, siły Unii Europejskiej miały osiagnąć poprzez: pomoc w odbudowie instytucji państwowych, pomoc przy reformach państwa, w szczególności resortów siłowych oraz sprawiedliwości, ochronę granic, odbudowę stabilnego systemu demokratycznego oraz walkę z przejawami łamania praw człowieka. Oddziały UE miały także wesprzeć takie przemiany polityczne, społeczne, gospodarcze w tym kraju, które pozwoliłyby na szybkie zbliżenie Bośni i Hercegowiny do Unii Europejskiej. Jest to misja o zdecydowanie większej skali niż w przypadku Concordii. Uczestniczyło w niej początkowo 7000 żołnierzy, jednak później siły te zostały zredukowane do 2500. Jest ona prowadzona do dnia dzisiejszego i należy ją uznać za duży sukces Unii Europejskiej. W odróżnieniu od działań w Macedonii, w operacji Althea uczestniczą zdecydowanie większe siły wojskowe a reformy demokratyczne Bośni i Hercegowiny idą w dobrym kierunku, co potwierdza skuteczność realizacji założonych w 2004 roku zadań ${ }^{12}$.

W następnych latach uwaga Unii Europejskiej zwróciła się, głównie za sprawą Paryża, na kontynent afrykański. W perspektywie stosunków francusko-amerykańskich, krok ten nie powinien był rodzić większych kontrowersji. USA silnie zaangażowane na Bliskim Wschodzie i w Afganistanie, nie wykazywały wówczas większego zainteresowania Czarnym Kontynentem. Pierwszą afrykańską operacją UE była misja wojskowa Artemis w Republice Demokratycznej Konga. Jak zauważył Yves Boyer, pozwoliła ona przetestować tworzone od 1999 roku europejskie mechanizmy decydowania, planowania i podejmowania operacji wojskowych Unii Europejskiej ${ }^{13}$. Przygotowania do przerzutu sił Unii Europejskiej do RDK zostały podjęte w czerwcu 2003 roku. Mandat operacji oparto na rezolucji Rady Bezpieczeństwa ONZ nr 1484 i decyzji Rady Unii Europejskiej z 5 czerwca 2003 roku. Głównym celem sił UE było zapewnienie bezpieczeństwa i warunków stabilizacji opuszczonemu przez siły Ugandy regionowi Iturii (okolice miasta Bunia), do czasu przybycia tam dodatkowych oddziałów Organizacji Narodów Zjednoczonych ${ }^{14}$. W sumie Unia Europejska oraz inne państwa uczestniczące wysłały do Konga 1800 żołnierzy. Misja zakończyła się już po trzech miesiącach we wrześniu 2003 roku po przekazaniu odpowiedzialności za Ituri jednostkom ONZ. Trzeba przy tym zauważyć, że głównym promotorem operacji Artemis była Francja, tradycyjnie zainteresowana sytuacją bezpieczeństwa w Afryce. V Republika stała się wiodącym uczestnikiem działań UE w Kongo (nation-cadre; framework na-

11 R. Zięba, Unia Europejska jako aktor stosunków międzynarodowych, Warszawa 2003, s. 122.

12 R. Zięba, Europejska Polityka Bezpieczeństwa i Obrony, Warszawa 2003, s. 88-89; Council Joint Action 2004/570/CFSP of July 122004 on the European Union Military Operation in Bosnia and Hercegowina, Official Journal of the European Union, 28.07.2004; EU Military Operation in Bosnia and Hercegowina (EUFOR-Althea), http://consilium.europa.eu/cms3 fo/showPage.asp?id=745\&lang=en, dostęp: 17.09.2008; M. Musioł, Bezpośrednie zaangażowanie UE w utrzymanie pokoju w Europie, Portal Spraw Zagranicznych, 20.06.2007, s. 8, www.psz.pl.

${ }^{13}$ Y. Boyer, La sécurité et la défense: le temps des militaires, „Questions Internationales”, nr 7, s. 6.

14 C. Piana, op. cit., s. 95. 
tion) o czym świadczył chociażby fakt, że dostarczyła ona ok. $80 \%$ sił biorących udział w operacji, a dowódcą sił unijnych został Francuz gen. Bruno Neveux ${ }^{15}$.

W trzy lata później, w 2006 roku Unia Europejska podjęła kolejną operację w Demokratycznej Republice Konga - EUFOR RD Congo. Powodem jej rozpoczęcia były zbliżające się wybory prezydenckie i parlamentarne w tym kraju i związane z nimi ryzyko destabilizacji. Mandat operacji oparto na rezolucji Rady Bezpieczeństwa Organizacji Narodów Zjednoczonych nr 1671. Do głównych zadań EUFOR Congo zaliczono: wsparcie działań sił Organizacji Narodów Zjednoczonych (MONUC), ochronę lotniska w Kinszasie oraz zapewnienie bezpieczeństwa obserwatorom Unii Europejskiej oraz pracownikom ONZ. EUFOR miało także interweniować w przypadku wybuchu zamieszek w stolicy. W misji uczestniczyło 2500 żołnierzy z kilkunastu krajów Europy oraz Turcja. Największym udziałowcem była oczywiście Francja, będąca jednym z inicjatorów tej operacji - w skład EUFOR RD Congo weszło ok. 1000 francuskich żołnierzy. Wojska francuskie użyczyły również odpowiedniej infrastruktury oraz rezerw operacyjnych $^{16}$. Operacja zakończyła się sukcesem 30 listopada 2006 roku $^{17}$.

Ostatnią ważną misją wojskową Unii Europejskiej na początku XXI wieku jest EUFOR Tchad/RCA, realizowana na podstawie rezolucji Rady Bezpieczeństwa ONZ nr 1778 z września 2007 roku. Głównym powodem rozmieszczenia w Czadzie sił Unii Europejskiej jest stale nierozwiązany konflikt w Darfurze. Jest to także największa operacja, jaką Unia Europejska dotychczas przeprowadziła na kontynencie afrykańskim. EUFOR Tchad/RCA miało realizować 3700 żołnierzy, rozmieszczanych w tym regionie sukcesywnie od stycznia 2008 roku. W rzeczywistości w Czadzie i Republice Środkowoafrykańskiej stacjonuje obecnie ok. 3000 żołnierzy. Do głównych zadań tych sił należy: zapewnienie stabilizacji i bezpieczeństwa we wschodnim Czadzie, pomoc dla misji ONZ oraz ochrona i pomoc humanitarna dla miejscowej ludności i dla uchodźców. Trzeba przy tym zauważyć, że również w tym wypadku głównym inicjatorem i uczestnikiem tej misji jest Francja. Wielokrotnie przedstawiciele V Republiki, w tym m.in. minister spraw zagranicznych Bernard Kouchner w listopadzie 2007 r., wypowiadali się, jak duże znaczenie Francja przykłada do zatrzymania rozlewu krwi w Darfur rze $^{18}$. W tym wypadku, Paryż wysłał do Czadu ok. 2000 żołnierzy, czyli więcej niż

15 Ł. Kulesa, Operacje pokojowe w Afryce-implikacje dla Polski, „Biuletyn”, nr 61, Polski Instytut Spraw Międzynarodowych 2005, s. 2; K. Miszczak, Battle Groups/Grupy Bojowe - Europejskie Sity Szybkiego Reagowania, „Przegląd Środkowoeuropejski”, nr 40; Council Joint Action 2003/243/CFSP of 5 June 2003 on the European Union Military Operation in the Democratic Republic of Congo, Official Journal of the European Union, 11.06.2003; EU Military Operation in Democratic Republic of Congo (DRC/Artemis), http://consilium.europa.eu/cms3_fo/showPage.asp?id=1091\&lang=en, dostęp: 17.09.2008; R. Zięba, Europejska Polityka Bezpieczeństwa i Obrony, Warszawa 2003, s. 90; A. Dulphy, C. Manigand, op. cit., s. 231; Y. Boyer, Les operations militaires et de Police de l'Union européenne, w: Annuaire Stratégique et Militaire 2004, Paris 2004, s. 3-4.

16 Operation EUFOR RD Congo-Benga, www.defense.gouv.fr, dostęp: 5.02.2009.

17 EUFOR RD Congo, http://consilium.europa.eu/cms3_fo/showPage.asp?id=1091\&lang=en, dostęp: 17.09.2008; B. Górka-Winter, Misja Unii Europejskiej w Demokratycznej Republice Konga (EUFOR RD Congo), „Biuletyn”, nr 44, Polski Instytut Spraw Międzynarodowych, s. 1-2.

18 Point de presse du ministre des affaires étrangères et européennes, M. Bernard Kouchner, a l'Institut du Monde Arabe, Déclarations de politique étrangère, Paris 5.11.2007; Entretien du représentant permanent de la France aux Nations Unies avec ,France 24", ,RFI” et „, BBC Afrique”, New 
wszystkie pozostałe państwa Unii Europejskiej, co udowodniło, jak duże znaczenie dla Pałacu Elizejskiego ma ta operacja ${ }^{19}$.

Ponadto, Unia Europejska od 2000 roku podejmowała szereg operacji na mniejszą skalę. Na uwagę zasługują tu m.in. kolejne misje w Afryce, czyli EUPOL Kinshasa w Republice Demokratycznej Konga, EU Support to Amis w Darfurze, EUJUST Lex w Iraku, EUPOL w Afganistanie czy EU SSR w Gwinei-Bissau ${ }^{20}$. Nie trudno więc zauważyć, porównując dwa okresy, lat 90-tych XX w. i początku XXI wieku, że aktywność Unii Europejskiej pod tym względem znacząco wzrosła. Przy czym, działania Unii dotyczyły tak wymiaru cywilnego (misje monitorujące, wspierania reform czy policyjne), który jest łatwiejszy do realizacji, jak i wymiaru wojskowego, który był dotychczas największym wyzwaniem. Zjednoczona Europa od 2000 roku, wysłała w różne rejony świata w sumie kilkanaście tysięcy żołnierzy, a każda z jej operacji wojskowych kończyła się jak dotąd sukcesem. Co prawda, w porównaniu do działań NATO nadal jest to niewiele, ale trzeba odnotować, że zdolności UE w tej dziedzinie wielokrotnie się powiększyły.

Wszystkie cywilne i wojskowe działania podejmowane przez Unię na arenie międzynarodowej spotykały się ze stałym poparciem Paryża. W większości przypadków, to właśnie Pałac Elizejski był głównym inicjatorem i uczestnikiem działań podejmowanych w tej dziedzinie. Przykładowo, Francuzka, Maryse Daviet stanęła na czele misji EUMM w byłej Jugosławii. Ponadto, Francja była jednym z inicjatorów pierwszego szczytu Unia Europejska-Zachodnie Bałkany w Zagrzebiu w listopadzie 2000 roku $^{21}$. Zaangażowanie V Republiki w misje zarządzania kryzysowego UE stało się szczególnie widoczne w przypadku działań podejmowanych na kluczowym dla niej kierunku - w Afryce. To właśnie Francja była z reguły ich głównym inicjatorem i udziałowcem ${ }^{22}$. Niesłabnące poparcie Paryża dla realizacji misji zarządzania kryzysowego potwierdzały także cele, jakie sformułował on podczas swej prezydencji w UE w 2000 roku. Wśród najważniejszych zadań wymieniono wtedy: rozwój cywilnych i wojskowych zdolności zarządzania kryzysowego UE, rozbudowę struktur zajmujących się tym aspektem ESDP oraz podpisanie odpowiednich porozumień $\mathrm{w}$ tej sprawie z NATO i krajami trzecimi ${ }^{23}$. W czerwcu 2008 roku, cele kolejnej francuskiej prezydencji w Unii Europejskiej pozostały podobne. Sekretarz Stanu ds. Europejskich Francji Jean-Pierre Jouyet podczas spotkania Rady Północnoatlantyckiej podkreślił szybki rozwój zdolności UE w dziedzinie zarządzania kryzysowego, biorąc pod uwagę, iż

York 27.11.2007; Intervention du représentant permanent de la France au Conseil de Sécurité des Nations Unies, New York 27.11.2007, http://pastel.diplomatie.gouv.fr, dostęp: 5.02.2009.

19 Sytuacja w Czadzie - polska misja pod flaga UE i ONZ, Parlament Europejski - Briefing, 6.03.2008, http://www.europarl.europa.eu/sides/getDoc.do?language=PL\&type=IM-PRESS\&reference=20080219BRI21798\&secondRef=ITEM-011-PL, dostęp: 17.09.2008; EUFOR Tchad/RCA, http://consilium.europa.eu/cms3_fo/showPage.asp?id=1366\&lang=en, dostęp: 17.09.2008.

20 Zob. m.in. R. Zięba, Europejska Polityka Bezpieczeństwa i Obrony, Warszawa 2003, s. 86-94.

$21 \mathrm{http} / / / \mathrm{www}$. consilium.europa.eu/cms3_fo/showPage.asp?id=623\&lang=EN\&mode=g, dostęp: 17.09.2008.

22 A. Szeptycki, Francja czy Europa? Dziedzictwo generała de Gaulle'a w polityce zagranicznej V Republiki, Warszawa 2005, s. 301.

${ }^{23}$ La Role de France dans la PESD, Représentation permanent de la France aupres de l'Union Européenne, www.rpfrance.eu, dostęp: 17.09.2008. 
przez ostatnie 10 lat (od szczytu w St. Malo) Unia Europejska przeprowadziła prawie 20 cywilnych i wojskowych operacji na całym świecie. W tym kontekście, jednym z głównych celów francuskiej prezydencji stała się analiza dotychczasowych doświadczeń w tej dziedzinie, co pozwoliłoby na dalszy rozwój unijnych zdolności planowania i podejmowania misji ,,dostosowanych do europejskich potrzeb”. Obok tego, dla V Republiki równie ważne było zaktualizowanie europejskiej strategii bezpieczeństwa oraz rewitalizacja Europejskiej Agencji Obrony. Odnosząc się do stosunków pomiędzy Unią Europejską a Sojuszem Północnoatlantyckim w tym kontekście, Jean-Pierre Jouyet stwierdził, że wymienione wyżej działania staną się częścią „odnowionej wizji politycznej” opartej na „uzupełniającej się Europie obrony i NATO”24. Wagę jaką Francja przywiązuje do tego aspektu działań Unii Europejskiej potwierdził również fakt, iż kraj ten dostarczył ponad 10\% wszystkich żołnierzy, policjantów oraz cywilnych obserwatorów i doradców, którzy wzięli udział w misjach unijnych od 2000 roku $^{25}$. V Republika stała się także jednym z inicjatorów ,grup bojowych” Unii Europejskiej, czyli samodzielnych, 1500-osobowych jednostek wojskowych, zdolnych do podjęcia działań w ciągu 15 dni od otrzymania rozkazu ${ }^{26}$. Warto tu przytoczyć opinię Y. Boyer, według którego od początku XXI wieku, to właśnie Francja, obok Niemiec i Wielkiej Brytanii jest motorem napędowym Europejskiej Polityki Bezpieczeństwa i Obrony. Świadczy o tym wysoki udział V Republiki w całościowo ujętych zdolnościach wojskowych Unii Europejskiej. Przykładowo floty Francji i Wielkiej Brytanii przed 2004 rokiem reprezentowały ok. 50\% flot 15 krajów Unii Europejskiej, a wydatki zbrojeniowe tych dwóch krajów oraz Niemiec stanowiły więcej niż 2/3 wszystkich wydatków zbrojeniowych $\mathrm{UE}^{27}$. Po rozszerzeniu Unii w 2004 roku stosunek ten uległ jedynie niewielkiej zmianie.

W oparciu o powyższe rozważania, pojawia się problem wpływu aktywizacji UE na arenie międzynarodowej oraz francuskich przedsięwzięć w tej dziedzinie na charakter stosunków francusko-amerykańskich. Na kwestię tę, należałoby spojrzeć z dwóch perspektyw.

Stany Zjednoczone od lat postulowały przejęcie przez Europę większej odpowiedzialności (tzw. burden sharing) za swoje bezpieczeństwo. Rozwój stosunków NATO-Unia Europejska na początku XXI wieku wskazywał na to, iż Stany Zjednoczone nie są przeciwne podejmowanym przez zjednoczoną Europę samodzielnym misjom

24 J.-P. Jouyet, The goals of the French EU presidency presented to the North Atlantic Council, Brussels, 16.07.2008, http://www.diplomatie.gouv.fr/en/france-priorities_1/international-organizations_1100/international-organization-in-europe_2482/nato-north-atlantic-treaty-organization_2095/nato-and-the-eu_6487/the-goals-of-the-french-eu-presidency-presented-to-to-the-north-atlantic-council16.07.08_11660.html, dostęp: 17.09.2008.

${ }_{25}$ La Role de France dans la PESD, Représentation permanent de la France aupres de l'Union Européenne, www.rpfrance.eu, dostęp: 17.09.2008.

26 Por. Y. Boyer, 2005: un bilan mitigé pour la PESD, „Notes de la FRS”, Fondation pour la Recherche Stratégique 2005; K. Miszczak, Battle Groups/Grupy Bojowe - Europejskie Sity Szybkiego Reagowania, „Przegląd Środkowoeuropejski”, nr 40; A. Dulphy, C. Manigand, op. cit., s. 231; Y. Boyer, Les armées européennes aux prises avec la multinationalite, „Annuaire Francais de Relations Internationales" 2006, vol. VII, Bruxelles 2006.

${ }^{27}$ Y. Boyer, La sécurité et la défense: le temps des militaires, „Questions Internationales”, nr 7, s. $8-9$. 
wojskowym, pod warunkiem, że ich przeprowadzeniem nie będzie zainteresowany Pakt Północnoatlantycki. Takie rozwiązanie mogło odpowiadać obu stronom z dwóch powodów. Po pierwsze, czego pragnął Waszyngton, Sojusz Północnoatlantycki nadal pozostawał główną organizacją „twardego" bezpieczeństwa obszaru transatlantyckiego, mając pierwszeństwo angażowania się w misje zarządzania kryzysowego. Po drugie, Unia Europejska uzyskała na początku XXI wieku dostęp do środków Sojuszu oraz możliwość angażowania się na kierunkach, na których desinteressement wyraziło NATO i Stany Zjednoczone. Potwierdza to także fakt, że USA, NATO i Unia Europejska, mimo pewnych trudności (związanych przede wszystkim z napięciami wywołanymi wojną w Iraku), blisko ze sobą współpracowały przy przygotowaniu i prowadzeniu operacji Unii Europejskiej na Bałkanach ${ }^{28}$.

Na rozwój unijnych zdolności w dziedzinie misji zarządzania kryzysowego można jednak spojrzeć z innej strony. Od wydarzeń w Kosowie, a potem w Iraku Europa, w tym i Francja, starała się podejmować autonomiczne wobec Sojuszu Północnoatlantyckiego działania. Mogło to w Waszyngtonie rodzić obawy, że budowa Wspólnej Polityki Zagranicznej i Bezpieczeństwa będzie jednak zagrożeniem dla NATO. Potwierdził to Michael John Williams, który zauważył, że Stany Zjednoczone od lat starają się równoważyć europejskie starania w celu uzyskania zdolności ekspedycyjnych w obawie przed dyskryminacją lub dublowaniem struktur Paktu Północnoatlantyckiego. Jak jednak wskazał Williams, europejskie próby są „małym krokiem w dobrym kierunku” a proces ten powinien być w pełni poparty przez Waszyngton, ponieważ zapewni to przeciwdziałanie kryzysom tam, gdzie Biały Dom nie chce lub nie może interweniować $^{29}$. Pewne światło na stanowisko Stanów Zjednoczonych wobec misji przeprowadzanych przez Unię Europejską w XXI wieku rzucił również raport K. Archick i P. Gallis'a dla amerykańskiego Kongresu z 29 stycznia 2008 roku. Wskazano w nim pewne wątpliwości, które wyraża w tej kwestii strona amerykańska. Przede wszystkim, analitycy zauważyli francusko-amerykańskie napięcia wywołane silnie wspieranymi przez Paryż misjami Unii Europejskiej w Kongu. Dla amerykańskich i natowskich przedstawicieli misja w Kongo była zaskoczeniem ze względów geograficznych, gdyż Waszyngton nie spodziewał się, że UE zaangażuje się poważnie na innych obszarach niż Europa. Ponadto, w trakcie tej misji nie skorzystano ze środków Sojuszu Północnoatlantyckiego, bowiem cała operacja została przygotowana i zaplanowana przez dowództwo armii francuskiej. Unia Europejska nie zastosowała się do wcześniejszych porozumień dotyczących uzgadniania z NATO przeprowadzanych przez nią misji. Co prawda, odbyły się pewne konsultacje dotyczące samej operacji, ale UE nie zapytała oficjalnie Sojuszu o chęć zaangażowania się w tym regionie, co stanowiło złamanie

\footnotetext{
${ }^{28}$ Marko Mihajić zauważył tendencję w polityce zagranicznej Stanów Zjednoczonych w XXI wieku do stopniowego redukowania swojej obecności wojskowej na Bałkanach, co mogło pozytywnie wpłynąć na przejęcie odpowiedzialności za ten region przez Unię Europejską. Zob. M. Mihajić, Polityka wobec Bałkanów, w: Polityka zagraniczna USA po zimnej wojnie, red. J. Zając, Toruń 2006,

29 Zob. M. J. Williams, EU Battle Groups March Europe Toward Common Defense, Atlantic-Community, 25.06.2007, http://www.atlantic-community.org/index/Open_Think_Tank_Article/EU_Battlegroups_March_Europe_Toward_Common_Defense, dostęp: 17.09.2008.
} s. 113. 
wcześniejszych porozumień ${ }^{30}$. Poza tym, jak stwierdzono w raporcie, Stany Zjednoczone cały czas obawiają się, iż działania podejmowane głównie przez Francję w ramach ESDP doprowadzą do rywalizacji NATO i Unii Europejskiej i w rezultacie do zmniejszenia amerykańskich wpływów na Starym Kontynencie ${ }^{31}$. Wydaje się jednak, iż perspektywa ta stała się nieaktualna wraz z dojściem do władzy prezydenta Baracka Obamy. Prezydent ten zdaje się w pełni akceptować koncepcję nowego euroatlantyckiego systemu bezpieczeństwa, którą sformułował prezydent N. Sarkozy w latach 2007-2008. Zakładała ona oparcie tego systemu na dwóch równoprawnych filarach: Unii Europejskiej oraz NATO. Każdy z tych filarów, według francuskiego prezydenta, powinien realizować odmienne zadania, przy czym Sojusz pozostałby organizacją „twardego bezpieczeństwa”, podczas gdy UE zajęłaby się wyzwaniami o nieco mniejszej skali ${ }^{32}$. Z pewnością za symbol francusko-amerykańskiego porozumienia $\mathrm{w}$ tej dziedzinie można uznać francuską reintegrację z NATO w marcu 2009 roku.

Można więc stwierdzić, iż problem operacji militarnych Unii Europejskiej w kontekście stosunków francusko-amerykańskich i unijno-natowskich zawierał w sobie tak elementy rywalizacji, jak i współpracy. Z jednej strony, zrozumiałe były francusko-amerykańskie napięcia wywołane coraz lepiej zorganizowanymi, szerzej zakrojonymi i coraz bardziej niezależnymi od NATO operacjami Unii Europejskiej. Z drugiej jednak, należy pamiętać, że duża część tych misji była prowadzona przy współpracy z NATO i Stanami Zjednoczonymi (jak to miało miejsce w wypadku misji na Bałkanach). Ponadto, Unia Europejska, mimo niebywałego postępu w ostatnich latach, osiągniętego w dużej mierze dzięki francuskim inicjatywom, nadal nie posiada środków nawet częściowo odpowiadających potencjałowi NATO i Stanów Zjednoczonych. Co za tym idzie, amerykańskie obawy o możliwość rywalizacji UE i NATO wydawały się nie mieć podstaw. Potwierdził to zresztą Yves Boyer, według którego, zdolności militarne państw Europy nie tylko, nie powiększają się, ale wręcz maleją. Wynika to m.in. z faktu nieustannego zmniejszania sił zbrojnych krajów o dotychczas dużych potencjałach wojskowych: Wielkiej Brytanii czy Holandii ${ }^{33}$. Poza tym, stanowisko Francji względem Unii Europejskiej i NATO pozostaje od lat niezmienne. Zarówno Francja J. Chiraca, jak i N. Sarkozy’ego popiera budowę autonomicznych zdolności wojsko-

${ }^{30}$ Zgodnie z wcześniejszymi uzgodnieniami (m.in. z Helsinek) Unia Europejska powinna oficjalnie zapytać NATO czy zamierza on podjać operację w Kongo. Takich działań Bruksela jednak nie podjęła, co wzbudziło irytację Waszyngtonu. Więcej na ten temat V. Bonniot, Le sic de l'UE ou la necessaire interoperabilite, $\mathrm{w}$ : La sécurité de l'Europe et les relations transatlantiques au seuil du XXI siècle, dir. Y. Jeanclos, Bruxelles 2003, s. 385-390; M. Bacot-Decriaud, La nouvelle relations Union Européenne-OTAN en matière de sécurité et de défense: competition ou cooperation?, w: La sécurité de l'Europe et les relations transatlantiques au seuil du XXI siècle, dir. Y. Jeanclos, Bruxelles 2003, s. 370-372; Y. Jeanclos, La non-armée de l'Union Européen a l'orée de XXI siècle, w: La sécurité de l'Europe et les relations transatlantiques au seuil du XXI siècle, dir. Y. Jeanclos, Bruxelles 2003, s. $299-300$.

31 K. Archick, P. Gallis, NATO and European Union, „CRS Report for Congress”, 29.01.2008, s. $23-27$.

32 S. Serfaty, S. Biscop, A Shared Security Strategy for a Euro-Atlantic Partnership of Equals, Center for Strategic \& International Studies, july 2009.

${ }^{33}$ Y. Boyer, 2005: un bilan mitigé pour la PESD, „Notes de la FRS”, Fondation pour la Recherche Stratégique 2005, s. 4-6. 
wych Unii Europejskiej, które nie będą jednak konkurencyjne, ale komplementarne wobec Sojuszu Północnoatlantyckiego. Warto tu przytoczyć zresztą opinię Dominique’a David'a, który potwierdził, iż Paryż od lat dąży do takiej rozbudowy ESDP, która uzupełniałaby, a nie zastępowała NATO, głównie, choć nie tylko, jeśli chodzi o misje zarządzania kryzysowego (gestion des crises) ${ }^{34}$. Podobne zdanie sformułowała Josiane Tercinet, która zauważyła, że kryzysy w Europie, a w szczególności ten w Macedonii udowodniły, że współpraca polityczna i militarna UE i NATO jest niezbędna ${ }^{35}$. Z tego też względu wydaje się, że pomimo wcześniejszych obaw, nowa administracja amerykańska zrozumiała, iż rozwój Wspólnej Polityki Zagranicznej i Bezpieczeństwa UE nie jest czynnikiem osłabiającym, ale wręcz wzmacniającym pozycję USA na arenie międzynarodowej.

34 D. David, France/OTAN: la dernière marche, ,Politique étrangère” 2008, nr 2, Institut francais de relations internationales, s. 434-436.

35 J. Tercinet, L'impossible monopole européen, w: La sécurité de l'Europe et les relations transatlantiques au seuil du XXI siecle, dir. Y. Jeanclos, Bruxelles 2003, s. 285. 
